\title{
Analysis Of E-Learning Acceptance During Distance Learning Using Unified Theory Of Acceptance And Use Of Technology (UTAUT)
}

\author{
Rifqi Ramadhan Tussardi ${ }^{1}$, Berlian Maulidya Izzati $^{2}$, Muhardi Saputra ${ }^{3}$ \\ ${ }^{1,2,3}$ Information System, School of Industrial Engineering, Telkom University, Bandung \\ e-mail: *11rifqirt@student.telkomuniversity.ac.id, ${ }^{2}$ berlianmi@telkomuniversity.ac.id, \\ 3muhardi@telkomuniversity.ac.id
}

\begin{abstract}
The new coronavirus disease that was first identified in Wuhan, China, is referred to as the 2019 coronavirus disease pandemic (COVID-19). The impact of this pandemic has affected various fields, one of which is education, and one of the consequences is the implementation of online teaching and learning processes. In this digital era, Telkom University is implementing CeLOE LMS as an E-Learning medium. CeLOE Learning Management System (LMS) is an online learning platform for regular and distance education study programs at Telkom University. For the application of CeLOE LMS, there has been no report that contains user acceptance of the use of CeLOE LMS that tested with an integrated model. Therefore, the solution offered by this research was to conduct an analysis to determine user acceptance of the application of the CeLOE LMS system by using the Unified Theory of Acceptance and Use of Technology (UTAUT) Model at Telkom University to produce report that can be used as a basis for further decision making by Telkom University in managing its services as the UTAUT Model attempts to clarify the intentions of students to use an information system and the usage actions of students. From this research, it was found that the CeLOE LMS has been accepted and used by Telkom University students with all hypotheses accepted, Performance Expectancy as the variable with the greatest influence, and it needs improvements related to technical infrastructure, organizational infrastructure, and socialization of CeLOE LMS due to the influence of Facilitating Conditions variable was the lowest.
\end{abstract}

Keywords - CeLOE LMS, COVID-19, Distance Learning, E-Learning, UTAUT.

\section{INTRODUCTION}

$\mathrm{F}$ rom the end of 2019 to 2020 has been the year when the whole world is brought together in a situation that all countries are not ready to face. Days turn to days, weeks turn to weeks, months turn months until we realize that this pandemic is not a temporary one, but we must be prepared to be faced with living with it until maybe years later. The disease caused by the novel coronavirus, which was first identified in Wuhan, China, is called the 2019 coronavirus disease (COVID-19) - 'CO' stands for corona, 'VI' for virus, and 'D' for disease. Previously, this disease was referred to as '2019 novel coronavirus' or '2019-nCoV' [1].

One of the impacts of the 2019-20 Coronavirus pandemic is on education around the world, which has led to the closure of large areas of schools, madrasas, universities, and Islamic boarding schools [2]. Communication in teaching and learning activities should be very effective, both between the teacher and the students and among the students themselves because the mechanism allows the student to get used to expressing opinions arguably and examining 
himself, whether what he knows is true or not, so that quality communication can occur [3]. In his research, Setiawan stated that UNESCO (United Nations Educational, Scientific and Cultural Organization) on March 4, 2020 suggested the use of distance learning and opened an educational platform that schools and teachers could use to reach learners remotely and limit educational distractions [2][4]. E-learning is separate learning that utilizes computer technology and networks (web) [5]. Furthermore, the Ministry of Education and Culture (Kemendikbud) has also made policies as a guide in dealing with this pandemic at the educational unit level [6].

The concept of e-learning is a new ICT-based learning technology that has been accepted in education. This acceptance is very reasonable in the context of preparing human resources with ICT capabilities to solve employment problems and economic stability [7]. E-learning or distance learning methods are computer-based learning methods and internet networks with little social interaction with peers and instructors so that all learning content is delivered digitally [8].

The Unified Theory of Acceptance and Use of Technology (UTAUT) model is an integrated model developed by Venkatesh et al. (2003) based on social cognitive theory with a combination of eight leading research models regarding the acceptance of information technology [19]. UTAUT is a combined model based on basic theories regarding technology user behavior and technology acceptance models, namely TRA, TAM, TPB, Motivational Model, Personal Computer Utilization Model, Innovation Diffusion Theory, and Social Cognitive Theory (SCT) [11]. In her research, Izzati stated that the UTAUT model can portray a few characteristics into a variable but the UTAUT model does not look at user fulfillment or performance impacts [21][22]. In Nasir's research, The UTAUT model has proven successful from the other eight technology acceptance theories in explaining up to $70 \%$ of user variants. The UTAUT model then developed with the addition of several variables [20][18]. The UTAUT model has four key constructs, namely: performance expectancy, effort expectancy, social influence, and facilitating conditions which have an influence on behavioral intention to use technology. The purpose of UTAUT is to assess the likelihood of success of a new technology and understand the level of acceptance of users. After going through further testing, Venkatesh and his colleagues found four fundamental builds that play an vital part as a direct determinant of behavioral intention and use behavior, namely, performance expectancy, effort expectancy, social influence, and facilitating conditions. Besides that, there are also four moderators: gender, age, voluntariness, and experience which are positioned to moderate the impact of the four main constructs on behavioral intention and use behavior [12]. Figure 1 illustrates UTAUT Model [18]. 


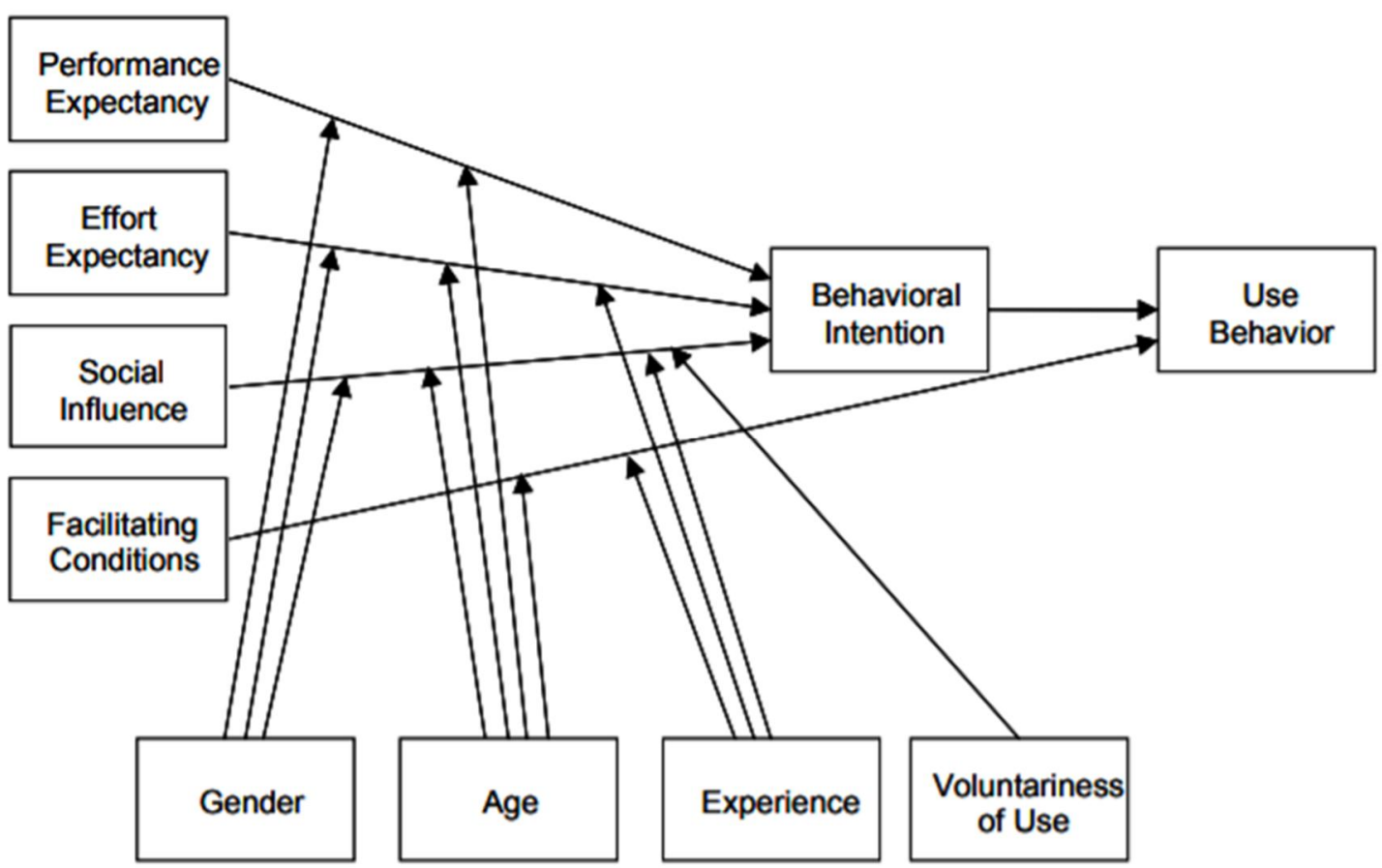

Figure 1. UTAUT Model

Performance expectancy is characterized as the degree to which an person accepts that utilizing the system will offer assistance for them to accomplish gains in work performance. The five constructs of the different models related to performance expectancy are perceived usefulness (TAM / TAM2 and C-TAM-TPB), extrinsic motivation (MM), job-fit (MPCU), relative-advantage (IDT), and outcome expectations (SCT) [18]; Effort expectancy is defined as the level of convenience associated with using the system. Three constructs of the existing model concurrently have the concept of effort expectancy: perceived ease of use (TAM / TAM2), complexity (MPCU), and ease of use [18]; Social influence is defined as the extent to which an individual feel that other people believe that he must use the new system. Social influence as a direct determinant of behavioral intention is represented as a subjective norm in TRA, TAM2, TPB / DTPB and C-TAM-TPB, social factors at MPCU, and image in SLI. Thompson et al. (1991) use the term social norm in defining its construct and acknowledge its similarity with subjective norms in TRA [18]; Facilitating conditions are defined as the extent to which a person believes that there is an organizational and technical infrastructure to support the use of the system. This definition captures the concept epitomized by three distinctive builds: perceived behavioral control (TPB / DTPB, C-TAM-TPB), facilitating conditions (MPCU), and compatibility (IDT). Each of these constructs is operationalized to include aspects of the technology and / or organizational environment outlined to evacuate boundaries to utilize [18]; Behavioral Intention (BI) is the extent to which one's consciousness has been formulated plans regarding whether to perform certain future behaviors [13]; Use behavior is the intensity and / or frequency of users using information technology. The behavior of using information technology is highly dependent on the evaluation of users of the system [18]; Gender defines the gender-specific of the respondent; Age defines how old the respondent is; Experience defines the experience of respondents using a system; Voluntariness of Use defines the extent to which the use of innovation is considered voluntary, or out of free will [18]. 


\section{METHODOLOGY}

The type of research in this research is quantitative research. This research points to decide the level of user acceptance of the CeLOE LMS e-learning where this goal is conclusive. Then seen from the type of investigation, this research is classified as correlational research. For this research the authors also did not intervene in the data in their research. Furthermore, the unit of analysis chosen by the author in this paper is the individual unit. Finally, based on the implementation time, this research uses a cross-sectional method.

\subsection{Stages}

As for the stages in this research can be described as follows:

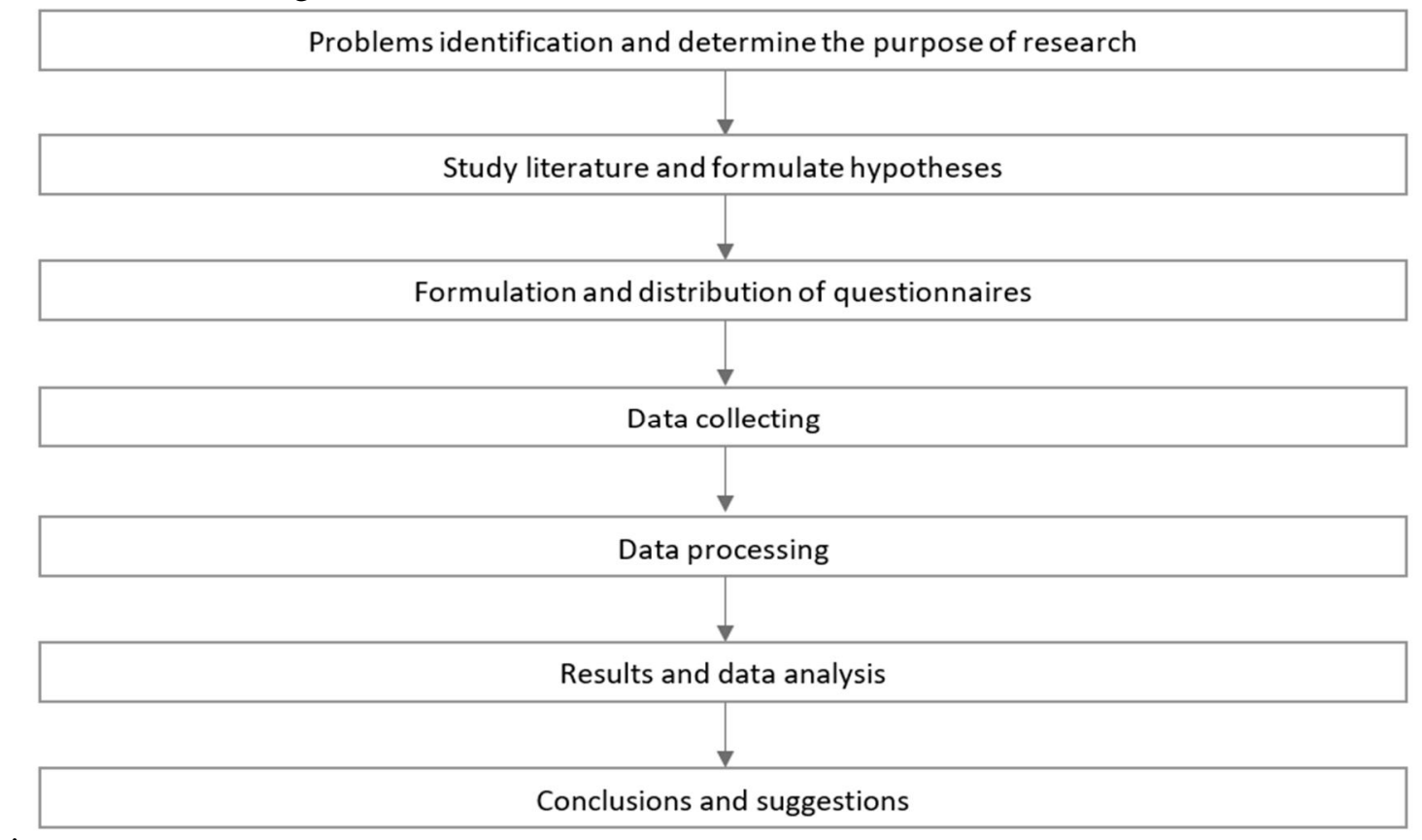

Figure 2. Research Stages

The research begans by identifying issues related to the acknowledgment and utilize of e-learning and understanding the background of the research. Then exploring existing theories to be used as a foundation in strengthening the author's research. Through this literature study, can be determined which variable that related to the problem and some provisional conclusions on the problem (hypothesis) also the analysis techniques that will be used by the author. Then formulating the questionnaires which later the results of the questionnaire will be used as data sources. The questionnaire was based on indicators that represent the variables in the research. The questionnaires that have been filled in by the respondents are collected so that they are used as data. Furthermore, the data that has been collected from the questionnaire will be processed using SPSS. From the results obtained, then the data were analyzed using the analytical method specified by the author. For the final, the author draws conclusions and provides suggestions for recommendations for next steps related to the research results. 


\subsection{Collecting Data Tools}

There are three types of variables that used in this research, namely independent variables, dependent variables, and moderating variables. They are described as follows:

- Independent Variable

The independent variables in this research are Performance Expectancy (X1), Effort Expectancy (X2), Social Influence (X3), And Facilitating Conditions (X4).

- Dependent Variable

Dependent variables in this research are Behavioral Intention (Y1) and Use Behavior (Y2).

- Moderator Variables

The moderator variables in this research are: Gender (Z1), Age (Z2), Experience (Z3), and Voluntariness of Use (Z4).

Data collection methods used in this paper is primary data. Data obtained from primary data must be further processed. Primary data collection is done online using a platform called Google Form, an online questionnaire which is an innovation from Google. For the scaling, the research is using an ordinal scale. All indicators are measured using a Likert scale with a range of 1 to 5 . Each number represents: number 1 - Strongly Disagree; number 2 - Disagree; number 3 - Neutral; number 4 - Agree; and 5 - Strongly Agree.

For the questionnaire, this research used 29 indicators or statements. In Performance Expectations measured by 8 statements; Effort Expectation measured by 5 statements; Social Influence measured by 6 statements; Facilitating Condition measured by 6 statatements; Behavioral Intention measured by a statement; and Use Behavior measured by 2 statements. An explanation of the hypothesis with the relationship between variables can also be seen in Figure 3.

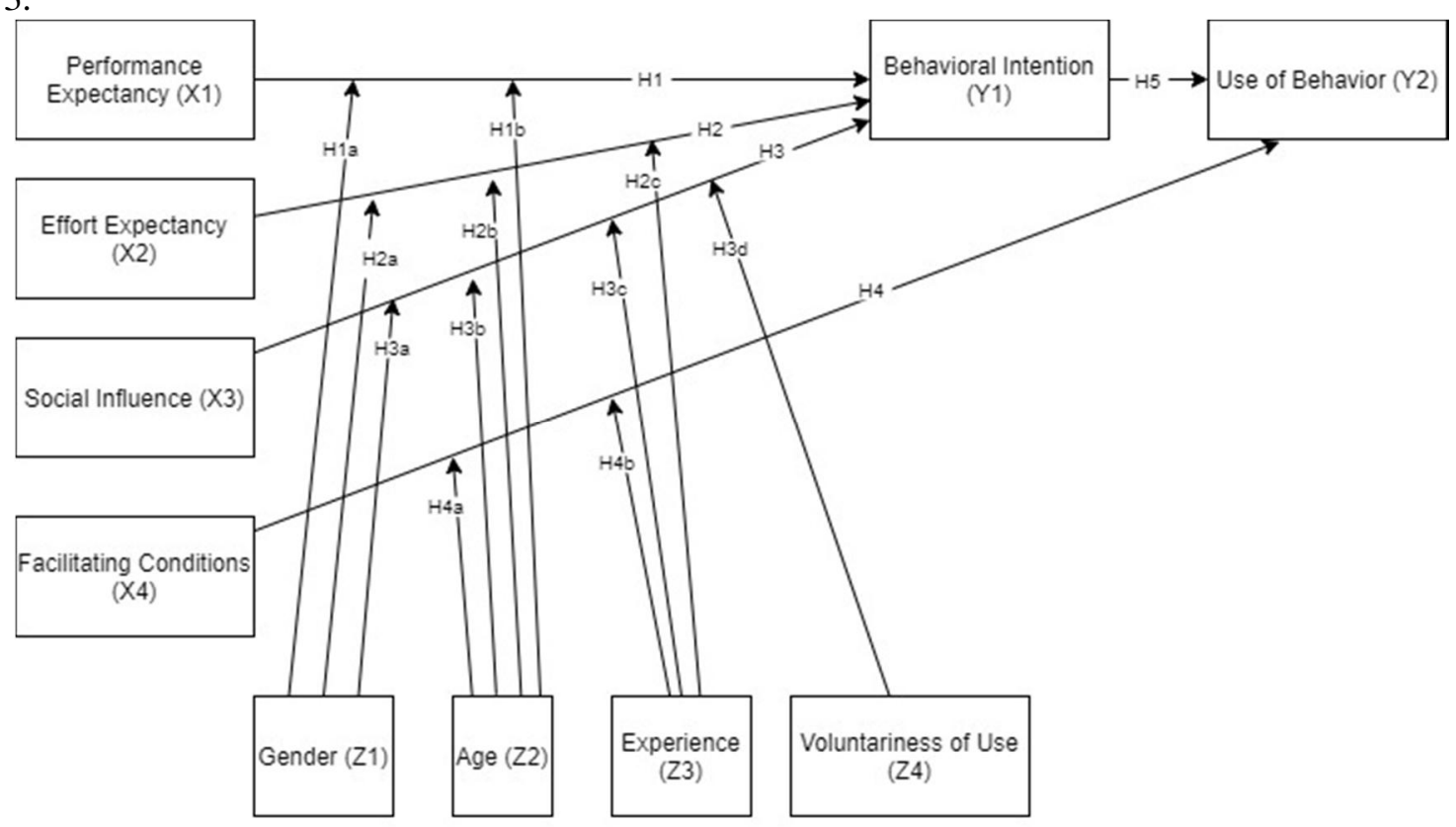

Figure 3. Hypothesis model [18].

Figure 3 above illustrates the hypothesis used in this research referring to the UTAUT 


\subsection{Data Analysis}

In analyzing the data, this paper uses descriptive analysis, validity and reliability tests, classical assumption tests, simple linear regression analysis which includes the coefficient of determination test along with the t-statistical test, and multiple linear regression analysis which includes the coefficient of determination test and the $\mathrm{F}$ test.

\subsection{Pilot Test}

\section{RESULT AND EXPLANATION}

This research was to begin with conducted to test the validity and reliability for the first time or moreover called pilot test. The validity test for questionnaire items used a significant level of 5\% with 30 respondents. These items were tested using IBM SPSS Statistics 26 software. From the Product Moment $r$ Value Table written in Sugiyono's book the $r$ table value was 0.374 [15]. The following is table 1 summaries of the results of the validity test in pilot test consist of 29 questionnaire items with 30 respondent.

Table 1. Validity Test in Pilot Test

\begin{tabular}{|l|l|l|l|}
\hline Item & Pearson Value & r-Table Value & Information \\
\hline VU1 & 0.554 & 0.374 & VALID \\
\hline PE1 & 0.639 & 0.374 & VALID \\
\hline PE2 & $\mathbf{0 . 2 6 8}$ & $\mathbf{0 . 3 7 4}$ & NOT VALID \\
\hline PE3 & 0.753 & 0.374 & VALID \\
\hline PE4 & 0.461 & 0.374 & VALID \\
\hline PE5 & $\mathbf{- 0 . 0 4 7}$ & $\mathbf{0 . 3 7 4}$ & NOT VALID \\
\hline PE6 & 0.598 & 0.374 & VALID \\
\hline PE7 & 0.642 & 0.374 & VALID \\
\hline PE8 & 0.769 & 0.374 & VALID \\
\hline EE1 & 0.445 & 0.374 & VALID \\
\hline EE2 & 0.4 & 0.374 & VALID \\
\hline EE3 & 0.406 & 0.374 & VALID \\
\hline EE4 & $\mathbf{0 . 1 7 8}$ & $\mathbf{0 . 3 7 4}$ & NOT VALID \\
\hline EE5 & 0.582 & 0.374 & VALID \\
\hline SI1 & $\mathbf{0 . 3 0 3}$ & $\mathbf{0 . 3 7 4}$ & NOT VALID \\
\hline SI2 & 0.412 & 0.374 & VALID \\
\hline SI3 & 0.586 & 0.374 & VALID \\
\hline SI4 & 0.638 & 0.374 & VALID \\
\hline SI5 & 0.676 & 0.374 & VALID \\
\hline SI6 & 0.475 & 0.374 & VALID \\
\hline SI7 & 0.724 & 0.374 & VALID \\
\hline & & & \\
\hline
\end{tabular}




\begin{tabular}{|l|l|l|l|}
\hline Item & Pearson Value & r-Table Value & Information \\
\hline FC1 & 0.416 & 0.374 & VALID \\
\hline FC2 & 0.498 & 0.374 & VALID \\
\hline FC3 & 0.761 & 0.374 & VALID \\
\hline FC4 & 0.473 & 0.374 & VALID \\
\hline FC5 & 0.476 & 0.374 & VALID \\
\hline FC6 & 0.736 & 0.374 & VALID \\
\hline BI1 & 0.767 & 0.374 & VALID \\
\hline UB1 & 0.529 & 0.374 & VALID \\
\hline UB2 & 0.431 & 0.374 & VALID \\
\hline
\end{tabular}

Based on table 1, it is known that of all 29 variables, there are 25 variables that are declared valid because they have a pearson correlation value above the $r$ table value. Meanwhile, the remaining 4, namely PE2, PE5, EE4, and SI1 were declared invalid.

The item deletion action is also carried out based on the person correlation value that does not exceed the $r$ table value. In this case, the value of $r$ table with a significance level of 5\% is 0.374 . Then, items that do not meet these conditions must be deleted for the variable to be valid.

Then performing data processing for reliability testing using the IBM SPSS Statistics 26 software which is presented in table 2 with the following results.

Table 2. Reliability Test in Pilot Test

\begin{tabular}{|r|r|}
\hline \multicolumn{2}{|c|}{ Reliability Statistics } \\
\hline Cronbach's Alpha & N of Items \\
\hline .901 & 30 \\
\hline
\end{tabular}

Based on table 2, it is known that the Cronbach's alpha value of all statement item variables has a value of 0.901 .

Obtained from Alhamdu in Safitri's research, table 3 below describes the range of Cronbach's Alpha reliability test scores [17] [9].

Table 3. Range of Reliability Test

\begin{tabular}{|l|l|}
\hline \multicolumn{1}{|c|}{ Score } & Information \\
\hline $0.80-1.0$ & Good \\
\hline $0.60-0.799$ & Acceptable \\
\hline$<0.60$ & Not good \\
\hline
\end{tabular}

Based on the table 2 and 3, it can be concluded that the value of 0.901 can be declared good.

\subsection{Characteristics}

The respondent's data were undergraduate students of Telkom University. The sample of this research was 100 respondents. The characteristics of the respondents were distinguished by gender, age, and experience in using e-learning. 
Table 4. Characteristics of

Respondents Based on Gender

\begin{tabular}{|l|l|l|}
\hline Gender & Frequency & Percentage \\
\hline Male & 51 & 51 \\
\hline Female & 49 & 49 \\
\hline Total & 100 & $100 \%$ \\
\hline
\end{tabular}

Based on the results in table 4 above, the acceptance was more in demand by male respondents than female respondents.

Table 5. Characteristics of

Respondents Based on Age

\begin{tabular}{|l|l|l|}
\hline Age & Frequency & Percentage \\
\hline 19 & 10 & $10 \%$ \\
\hline 20 & 17 & $17 \%$ \\
\hline 21 & 59 & $59 \%$ \\
\hline 22 & 12 & $12 \%$ \\
\hline 23 & 2 & $2 \%$ \\
\hline Total & 100 & $100 \%$ \\
\hline
\end{tabular}

Based on the data in table 5 above, this test was carried out by most respondents who were 21 years old.

Table 6 Characteristics of Respondents Based on Experience in Using E-Learning

\begin{tabular}{|l|l|l|}
\hline Experience & Frequency & Percentage \\
\hline Yes & 72 & $72 \%$ \\
\hline No & 28 & 28 \\
\hline Total & 100 & $100 \%$ \\
\hline
\end{tabular}

By looking at table 6 above, the majority of respondents have experience in using elearning other beside CeLOE LMS.

\subsection{Descriptive Analysis}

Measuring the mode of the distribution of answers from respondents to Performance Expectancy, it shows that on average the respondents agree on the questionnaire items in this variable. Based on the results of measuring the mode of the distribution of answers from respondents to Effort Expectancy, it shows that the average respondent agrees with the questionnaire items that are in this variable. Based on the results of measuring the mode of the distribution of answers from respondents to Social Influence, it shows that the average respondent is doubtful about the questionnaire items that are in this variable. Based on the results of measuring the mode of the respondent's distribution of answers to the Facilitating Condition, it shows that on average the respondents agree with the questionnaire items in this variable. Based on the results of measuring the mode of the distribution of answers from respondents to the Behavioral Intention, it shows that the average of respondents agrees with the 
questionnaire items in this variable. Based on the results of measuring the mode of the distribution of answers from the respondents to the Use Behavior, it shows that on average the respondents agree with the questionnaire items in these variables. Based on the results of measuring the distribution of answers from respondents to all items, it shows that the average respondent agrees with all the questionnaire items in this variable.

\subsection{Validity and Reliability}

In this research, re-tested was carried out for the validity of the questionnaire items using a significant level of 5\% with 100 respondents. These items were tested using IBM SPSS Statistics 26 software. From the Product Moment r Value Table written in Sugiyono's book, the $r$ table value was 0.202 [15]. The following is a table of 5 summaries of the results of the validity test totaling 25 questions with 100 respondents in this research.

Table 7. Validity Test

\begin{tabular}{|l|l|l|l|}
\hline Item & Pearson Value & R-Table Value & Information \\
\hline VU1 & 0.516 & 0.202 & VALID \\
\hline PE1 & 0.660 & 0.202 & VALID \\
\hline PE3 & 0.698 & 0.202 & VALID \\
\hline PE4 & 0.354 & 0.202 & VALID \\
\hline PE6 & 0.665 & 0.202 & VALID \\
\hline PE7 & 0.643 & 0.202 & VALID \\
\hline PE8 & 0.696 & 0.202 & VALID \\
\hline EE1 & 0.405 & 0.202 & VALID \\
\hline EE2 & 0.365 & 0.202 & VALID \\
\hline EE3 & 0.524 & 0.202 & VALID \\
\hline EE5 & 0.413 & 0.202 & VALID \\
\hline SI2 & 0.270 & 0.202 & VALID \\
\hline SI3 & 0.569 & 0.202 & VALID \\
\hline SI4 & 0.715 & 0.202 & VALID \\
\hline SI5 & 0.485 & 0.202 & VALID \\
\hline SI6 & 0.646 & 0.202 & VALID \\
\hline SI7 & 0.701 & 0.202 & VALID \\
\hline FC1 & 0.603 & 0.202 & VALID \\
\hline FC2 & 0.556 & 0.202 & VALID \\
\hline FC3 & 0.670 & 0.202 & VALID \\
\hline FC4 & 0.451 & 0.202 & VALID \\
\hline FC5 & 0.562 & 0.202 & VALID \\
\hline FC6 & 0.695 & 0.202 & VALID \\
\hline BI1 & 0.712 & 0.202 & VALID \\
\hline UB1 & 0.537 & 0.202 & VALID \\
\hline UB2 & 0.212 & 0.202 & VALID \\
\hline
\end{tabular}

Based on table 7, it is known that all 25 variables are declared valid because they have a Pearson correlation value above the $\mathrm{r}$ table value. 
In processing data for reliability testing using IBM SPSS Statistics 26 software with 100 respondents, the results are presented in table 8 with the following results.

Table 8. Reliability Test

\begin{tabular}{|r|r|}
\hline \multicolumn{2}{|c|}{ Reliability Statistics } \\
\hline Cronbach's Alpha & N of Items \\
\hline .906 & 100 \\
\hline
\end{tabular}

Referring to table 8 above, it is known that the Cronbach's alpha value of all statement item variables has a value above 0.80 or to be precise 0.906 so that the reliability of all statement item variables in this reserach can be declared good.

\subsection{Classic Assumption Test}

The classic assumption test was carried out for this research. The classical assumption tests used in this research were: Normality Test, Multicollinearity Test, and Heteroscedasticity Test.

The normality test was carried out using the Kolomogorov-Smirnov. The following table 9 is the result of the normality test that has been carried out using SPSS:

Table 9. Normality Test

\begin{tabular}{|l|l|}
\hline One-Sample Kolmogorov-Smirnov Test \\
\hline Asymp. Sig. (2-tailed) & 0.200 \\
\hline
\end{tabular}

The results of the normality based on table 9 above test using the Kolomogorov-Smirnov show a significance result (Asymp.sig) greater than 0.05, so it can be concluded that the data in this research were normally distributed.

Then for multicollinearity test, table 10 is the result of the multicollinearity test that has been carried out using SPSS:

Table 10. Multicolinearity Test

\begin{tabular}{|l|l|l|}
\hline \multicolumn{3}{|c|}{ Coefficients } \\
\hline Independent & Dependent & Sig. \\
\hline $\mathrm{X} 1$ & \multirow{3}{*}{ Y1 } & 0.000 \\
\cline { 1 - 1 } 2 & & 0.926 \\
\cline { 1 - 1 } X3 & & 0.891 \\
\cline { 1 - 1 } X4 & 0.003 \\
\hline
\end{tabular}

Based on the information within the table above, the four independent variables have a significance value (Sig.) Of less than 1 . So that it can be concluded that the multicollinearity test conducted shows significant results, there was no correlation between independent variables, and there was no multicolinearity symptoms.

For the heteroscedasticity, test was carried out using the Glejser test. The following table 11 is the result of the normality test that has been carried out using SPSS: 
Table 11. Heteroscedastisity Test

\begin{tabular}{|l|l|l|}
\hline \multicolumn{3}{|c|}{ Coefficients $^{\mathbf{a}}$} \\
\hline Independent & Dependent $^{\text {Sig. }}$ \\
\hline X1 & & 0.776 \\
\hline X2 & \multirow{2}{*}{ Abs_RES } & 0.218 \\
\cline { 1 - 1 } X3 & & 0.221 \\
\cline { 1 - 1 } X4 & & 0.246 \\
\hline
\end{tabular}

Based on the data within the table above, it can be seen that the significance value (Sig.) of the four independent variables is greater than 0.05 . So it can be concluded that the heteroscedasticity test that was carried out did not show an indication of heteroscedasticity.

\subsection{Determination Coefficient Test}

The coefficient of determination test was carried out on the variables with and without moderation which are described in the following table.

Table 12. Determination Coefficient

\begin{tabular}{|c|c|c|c|}
\hline Variable Relationship & Moderating Variable & Effect of Addition & Total Effect \\
\hline \multirow{3}{*}{$\mathrm{PE} \rightarrow \mathrm{BI}$} & - & - & $40,8 \%$ \\
\hline & Gender & $1,9 \%$ & $42,7 \%$ \\
\hline & Age & $0,1 \%$ & $40,9 \%$ \\
\hline \multirow{4}{*}{$\mathrm{EE} \rightarrow \mathrm{BI}$} & - & - & $21,2 \%$ \\
\hline & Gender & $2,6 \%$ & $23,8 \%$ \\
\hline & Age & $0,5 \%$ & $21,7 \%$ \\
\hline & Experience & $2 \%$ & $23,2 \%$ \\
\hline \multirow{5}{*}{$\mathrm{SC} \rightarrow \mathrm{BI}$} & - & - & $20,4 \%$ \\
\hline & Gender & $4,3 \%$ & $24,7 \%$ \\
\hline & Age & $2,2 \%$ & $22,6 \%$ \\
\hline & Experience & $6,6 \%$ & $27 \%$ \\
\hline & Voluntariness of Use & $14 \%$ & $34,4 \%$ \\
\hline \multirow{3}{*}{$\mathrm{FC} \rightarrow \mathrm{UB}$} & - & - & $10 \%$ \\
\hline & Age & $2,6 \%$ & $12,6 \%$ \\
\hline & Experience & $4,8 \%$ & $14,8 \%$ \\
\hline $\mathrm{BI} \rightarrow \mathrm{UB}$ & - & - & $12,8 \%$ \\
\hline
\end{tabular}

The calculation of the coefficient of determination test shows that all variables have a positive effect on the variables they influence. Then after adding the moderation variable, it also produces all moderation variables which are proven to strengthen their own relationship. Then 
the highest effect was achieved from testing the Performance Expectancy variable on Behavioral Intention. This means that average students believe using CeLOE LMS will help them increase productivity in the study process. As for the lowest score obtained from testing the Facilitating Conditions variable on Use of Behavior. This means that students believe that there was still a lack of influence from the organizational infrastructure and technical infrastructure to support the use of CeLOE LMS.

\subsection{Hypotheses Test}

This hypothesis testing is carried out on hypotheses do and do not contain moderator variables.

The following table 13 is the result of hypothesis testing which does not contain moderator variables using the t-statistic test.

Table 13. Hypotheses Test I

\begin{tabular}{|l|l|l|l|l|}
\hline Code & Variable Relationship & t-Statistics & t-Table & Decision \\
\hline H1 & PE $\rightarrow$ BI & 8,222 & 1,66 & Positive and Significant \\
\hline H2 & EE $\rightarrow$ BI & 5,127 & 1,66 & Positive and Significant \\
\hline H3 & SC $\rightarrow$ BI & 5,015 & 1,66 & Positive and Significant \\
\hline H4 & FC $\rightarrow$ UB & 3,292 & 1,66 & Positive and Significant \\
\hline H5 & BI $\rightarrow$ UB & 3,795 & 1,66 & Positive and Significant \\
\hline
\end{tabular}

The outcomes after testing was obtained that all t-Statistics > t-Table. So, it can be concluded that the hypotheses $\mathrm{H} 1, \mathrm{H} 2, \mathrm{H} 3, \mathrm{H} 4$, and $\mathrm{H} 5$ can be stated as positive and significant.

The following table 14 is the result of hypothesis testing which contain moderator variables using the $\mathrm{F}$ test.

Table 14 .Hypotheses Test II

\begin{tabular}{|c|c|c|c|c|}
\hline Code & Variable Relationship & Moderating Variable & F Anova & Decision \\
\hline H1a & \multirow{2}{*}{$\mathrm{PE} \rightarrow \mathrm{BI}$} & Gender & 23,834 & Accepted \\
\hline $\mathrm{H} 1 \mathrm{~b}$ & & Age & 22,110 & Accepted \\
\hline $\mathrm{H} 2 \mathrm{a}$ & \multirow{3}{*}{$\mathrm{EE} \rightarrow \mathrm{BI}$} & Gender & 9,984 & Accepted \\
\hline $\mathrm{H} 2 \mathrm{~b}$ & & Age & 8,893 & Accepted \\
\hline $\mathrm{H} 2 \mathrm{c}$ & & Experience & 9,686 & Accepted \\
\hline $\mathrm{H} 3 \mathrm{a}$ & $\mathrm{SC} \rightarrow \mathrm{BI}$ & Gender & 10,490 & Accepted \\
\hline
\end{tabular}

Tussardi, et., al [Analysis of E-Learning Acceptance During Distance Learning Using Unified Theory of Acceptance and Use of Technology (UTAUT)] 


\begin{tabular}{|c|c|c|c|c|}
\hline Code & Variable Relationship & Moderating Variable & F Anova & Decision \\
\hline $\mathrm{H} 3 \mathrm{~b}$ & & Age & 10,490 & Accepted \\
\hline $\mathrm{H} 3 \mathrm{c}$ & & Experience & 11,808 & Accepted \\
\hline $\mathrm{H} 3 \mathrm{~d}$ & & Voluntariness of Use & 16,805 & Accepted \\
\hline $\mathrm{H} 4 \mathrm{a}$ & \multirow{2}{*}{$\mathrm{FC} \rightarrow \mathrm{UB}$} & Age & 6,196 & Accepted \\
\hline $\mathrm{H} 4 \mathrm{~b}$ & & Experience & 5,579 & Accepted \\
\hline
\end{tabular}

The hypothesis test that containing moderator variables was obtained that F-Anova $>$ Ftable. Thus, it can be concluded that the hypotheses H1a, H1b, H2a, H2b, H2c, H3a, H3b, H3c, $\mathrm{H} 3 \mathrm{~d}, \mathrm{H} 4 \mathrm{a}$, and $\mathrm{H} 4 \mathrm{~b}$ can be declared accepted.

This means that using E-learning CeLOE LMS can help improve student performance in the lecture process. The use of this technology can also mean that the ease associated with using E-Learning CeLOE LMS has generated interest from users to use CeLOE LMS in helping students in the lecture process. In addition, some lecturers have also introduced CeLOE LMS as a center for collecting assignments carried out by Telkom University students. CeLOE LMS has also tried to support facilities in its use and this is also supported by regular maintenance activities to maintain or improve CeLOE LMS services, but the impact is less felt by the average student. For the final, students have the awareness to proceed using CeLOE LMS in the study process.

\section{CONCLUSION}

Based on the results of the rese, the level of acceptance of the use of CeLOE LMS can be concluded that the average respondent agrees with all questionnaire items. This shows that CeLOE LMS at Telkom University has been accepted and used by Telkom University students.

The variable that has the greatest influence is Performance Expectancy with its effect on Behavior-al Intention and the lowest is Facilating Conditions with its effect on Use Behavior. The variables Gender, Age, Experience, and Voluntariness of Use strengthen all their own relationships. The variable that has the greatest influence in strengthening is the Voluntariness of Use in strengthening the relationship between Social Influence and Behavioral Intention and the lowest in strengthening is the Age variable in strengthening the relationship between Performance Expectancy and Behavioral Intention.

\section{SUGGESTION}

The recommendations for improvement given was based on the result of Facilitating Conditions as the one that has lowest impact to the CeLOE LMS. The solutions are to increase the socialization of the use of the CeLOE LMS, improve the organizational infrastructure of the CeLOE LMS, and improve the technical infrastructure of the CeLOE LMS. 
For further research, it can be continued with other subjects, such as Telkom University Lecturers or else. Then the analysis can be tested with other approaches to get various perspectives on the behavior of using technology.

\section{REFERENCES}

[1] 2020, Frequently Asked Questions About Coronavirus Disease (Covid-19). (N.D.). $\quad$ Retrieved November 17, From Https://Www.Unicef.Org/Indonesia/Coronavirus/Faq

[2] Setiawan, A. R. 2020, Lembar Kegiatan Literasi Saintifik Untuk Pembelajaran Jarak Jauh Topik Penyakit Coronavirus 2019 (Covid-19), Edukatif: Jurnal Ilmu Pendidikan, 2(1), 28-37.

[3] Miftah, M. 2019, Strategi Komunikasi Efektif Dalam Pembelajaran, Jurnal Teknodik, 12(2), 084.

[4] Unesco. (2020, Desember 24). 290 Million Students Out of School Due To Covid-19: Unesco Releases First Global Numbers And Mobilizes Response. retrieved Desember 24, 2020 from Unesco: Https://En.Unesco.Org/News/290-Million-Students-Out-School-DueCovid-19-Unesco-Releases-First-Global-Numbers-Andmobilizes

[5] Aidah, S. 2019, Pemanfaatan E-Learning Sebagai Media Pembelajaran di STIA Al Gazali Barru (Suatu Studi Terhadap Pemanfaatan Model E-Learning Berbasis Software Claroline), Meraja Journal, 2(1), 1-12.

[6] Kemendikbud. (2020, Desember 24), Surat Edaran Nomor 3 Tahun 2020 Tentang Pencegahan Covid-19 pada Satuan Pendidikan, retrieved Desember 24, 2020 from Lldikti Wilayah I Sumatera Utara:Https://Lldikti1.Ristekdikti.Go.Id/Berkas/Semendikbud032020pencegahancorona.P df

[7] Inayat, I., Amin, R. U., Inayat, Z., \& Salim, S. S. 2013, Effects of Collaborative Web Based Vocational Education And Training (Vet) on Learning Outcomes, Computers And Education.

[8] Zhang, D., Zhou, L., Briggs, R. O., \&Amp; Nunamaker, J. F. 2006, Instructional Video In E-Learning: Assessing The Impact of Interactive Video on Learning Effectiveness, Information \&Amp; Management, 43(1), 15-27.

[9] Hardiyanti Safitri, Nim. 14540055 2018, Analisis Penerimaan dan Penggunaan Sistem ELearning pada Uin Raden Fatah Palembang Menggunakan Pendekatan Utaut, Diploma Thesis, Uin Raden Fatah Palembang.

[10] Khoirunnisak, Wahyu 2016, Implementasi Model Penerimaan Unified Theory of Acceptance and User of Technology (Utaut) Untuk Menganalisis Faktor-faktor 
Penerimaan Dosen Terhadap Penggunaan E-Learning Share-Its, Undergraduate Thesis, Institut Teknologi Sepuluh Nopember.

[11] Hormati, A. 2012, Pengujian Model Unified Theory of Acceptance and Use of Technology Dalam Pemanfaatan, Jurnal Akuntansi Multiparadigma, 3(April), 1-24.

[12] Sedana, I. G. N., \& Wijaya, S. W. 2012, Penerapan Model Utaut Untuk Memahami Penerimaan dan Penggunaan Learning Management System Studi Kasus: Experential ELearning of Sanata Dharma University, Jurnal Sistem Informasi, 5(2).

[13] Cimperman, M., Makovec Brenčič, M., \& Trkman, P. 2016, Analyzing Older Users' Home Telehealth Services Acceptance Behavior-Applying An Extended Utaut Model. International Journal of Medical Informatics, 90.

[14] Indrawati. 2015, Metode Penelitian Manajemen dan Bisnis: Konvergensi Teknologi Komunikasi dan Informasi, Refika Aditama, Bandung.

[15] Sugiyono. 2016, Metode Penelitian Kuantitatif, Kualitatif dan R\&D, Alfabeta, Bandung.

[16] Thompson, R. L., Higgins, C. A., and Howell, J. M. 1991,"Personal Computing: Toward A Conceptual Model of Utilization," Mis Quarterly (15:1), Pp. 124-143.

[17] Alhamdu. 2016, Analisis Statistik Dengan Program SPSS, Noer Fikri Offset, Palembang/

[18] Viswanath Venkatesh, Michael G. Morris, Gordon B. Davis, and Fred D. Davis, 2003, "User Acceptance of Information Technology: Toward A Unified View," Management Information Systems Research Center, University of Minnesota, Vol. 27, September

[19] Taiwo, A. A., Mahmood, A. K., dan Downe, A. G. 2012, User Acceptance Ofegovernment: Integrating Risk and Trust Dimensions With Utaut Model.International Conference On Computer \& Information Science (Iccis), Retrieved From Google Scholar.

[20] Nasir, M. 2013, Evaluasi Penerimaan Teknologi Informasi Mahasiswa di Palembang Menggunakan Model Utaut, Seminar Nasional Aplikasi Teknologi Informasi (Snati), 1(1), 15-2013. Https://Journal.Uii.Ac.Id/Snati/Article/View/3006

[21] Izzati, B. M. 2020, International Journal of Innovation In Enterprise System Vol. 04 No. 01 P. 23-34

[22] O. Isaac, Z. Abdullah, A. H. Aldholay, and A. Abdulbaqi Ameen. 2019, "Antecedents and Outcomes of Internet Usage Within Organisations In Yemen: An Extension of The Unified Theory of Acceptance and Use of Technology (Utaut) Model," Asia Pacific Manag. Rev., Vol. 24, No. 4, Pp. 335-354, Dec. 